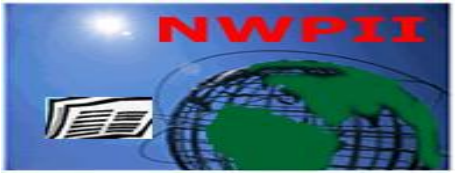

\title{
Characterization and Antibiotic Susceptibility of E. Coli O157:h7 in Meat and Fish Sold in Major Ibadan Markets, Nigeria
}

\author{
Oluwafunmilayo Abosede Ayodele ${ }^{1 *}$, Anotu Mope Deji-Agboola ${ }^{2}$, Adedayo Omotayo Faneye ${ }^{3}$, Paul \\ Akinniyi Akinduti ${ }^{4}$
}

${ }^{1}$ Department of Medical Microbiology, University College Hospital, Ibadan, Nigeria

2 Department of Medical Microbiology, Olabisi Onabanjo University, Sagamu campus, Nigeria

${ }^{3}$ Department of Virology, University of Ibadan, Ibadan, Nigeria

${ }^{4}$ Microbiology Unit, Department of Biological Sciences, Covenant University, Otta, Nigeria

*Corresponding Author

Dr. Ayodele Oluwafunmilayo Abosede

Department of Medical Microbiology

University College Hospital, Ibadan

Oyo State

Nigeria

Email: ayofunmi77@gmail.com

Phone: +23430706535

Received:20 December 2019; $\mid$ Revised:29 January 2020; $\mid$ Accepted:03 June 2020

\begin{abstract}
E. coli $\mathrm{O} 157: \mathrm{H} 7$ is one of the major causes of foodborne illness and it is of public health importance. Thus, the aim of this study was to isolate and characterize Escherichia coli O157:H7 from meat and fish sold in Ibadan markets. A total of 400 samples comprising of raw meat (beef, goat, pig, chicken, turkey) and fish (Sardine, Titus) were purchased from major markets in different parts of Ibadan. The samples were preenriched in tryptone soya broth at $37{ }^{\circ} \mathrm{C}$ for 24 hours, subcultured onto MacConkey, Blood and Sorbitol MacConkey agar plates. Thereafter, the organisms isolated were screened biochemically using Microbact GNB 12E. Antibiotic susceptibility and Double-disk synergy was performed using disc diffusion, Plate agglutination and PCR tests were used to identify E. coli O157:H7. 78 (19.5\%) of the isolates obtained were identified as E. coli. The incidence of E. coli serotype O157:H7 was $6(1.5 \%), 3(50 \%)$ carries eaeA, hly, $\mathrm{rfbE}$ and flich7 genes, 3(50\%) harboured flich7, rfbE and hly gene. The E. coli O157:H7 isolates were from beef $1(0.8 \%)$, chevon - $1(2.0 \%)$, pork $1(4.0 \%)$, Sardine fish $2(3.3 \%)$, Titus fish $1(1.7 \%) .4(66.7 \%)$ of the E. coli $\mathrm{O} 157: \mathrm{H7}$ isolated were resistant to two or more antibiotics. The resistance rate was very high in Ampicillin - 66.7\%, Cefuroxime - 66.7\% and Gentamicin - 50.0\%. The isolates were 100\% sensitive to Ceftazidime and Ciprofloxacin. The isolation of E. coli O157:H7 in raw meat/fish and the existence of antimicrobial resistant isolates highlight the potential threat to public health.
\end{abstract}

Keywords:Escherichia coli O157:H7, Markets, Raw meat, Raw fish, Antibiotics 


\section{Introduction}

Approximately 200 foodborne illnesses are recognized worldwide, but Enterohaemorrhagic Escherichia coli (EHEC) is considered among the most important bacterial pathogens to date ${ }^{[1]}$. E. coli $\mathrm{O} 157: \mathrm{H} 7$ is considered to be the archetypal and most infamous strain of the EHEC, because it is most commonly isolated from patients afflicted with haemorrhagic colitis and HUS ${ }^{[2,}{ }^{3]}$. The infectious dose of $E$. coli $\mathrm{O} 157: \mathrm{H} 7$ is reported to be as few as 1 to $100 \mathrm{CFU} / \mathrm{mL}^{[4,5]}$ which is lower than most other enteric pathogens. The low infectious dose exemplifies the potent virulence of $E$. coli $\mathrm{O} 157: \mathrm{H} 7$, and the virulence of this microorganism stems primarily from the activities of three major virulence factors ${ }^{[1]}$. E. coli $\mathrm{O} 157: \mathrm{H} 7$ infections occur worldwide and this have been reported on every continent except Antarctica [6]. Cattle faeces are the most important source of E. coli $\mathrm{O} 157: \mathrm{H} 7$, however, the presence of E. coli $\mathrm{O} 157: \mathrm{H} 7$ in the faeces of other animal species has been well recognized. Thus, it is distributed globally in the soil, water, vegetation, decaying matter, and the large intestine of most animals and humans ${ }^{[7]}$.

\section{Materials and Methods}

\subsection{Sample collection}

A total of 400 samples comprising of raw meat from beef $(\mathrm{n}=125)$, chevon (goat) $(\mathrm{n}=50)$, chicken $(\mathrm{n}=40)$, turkey $(\mathrm{n}=40)$ and pork $(\mathrm{n}=25)$, fish; sardine $(n=60)$, titus $(n=60)$, were purchased from major markets in different parts of Ibadan during the rainy and dry seasons. The samples were placed in separate sterile plastic bags to prevent cross contamination. All samples collected were immediately transported to the Microbiology Laboratory of the University College Hospital, Ibadan and processed within 2 hours.

\subsection{Isolation and Identification of $E$. coli}

Twenty-five (25) grams of each sample were homogenized in $225 \mathrm{ml}$ Tryptone Soya Broth and incubated at $37^{\circ} \mathrm{C}$ for $18-24$ hours. All the incubated samples were inoculated onto MacConkey agar plates and were incubated at $37^{\circ}$ $\mathrm{C}$ for 18 - 24 hours. Isolates were identified based on colonial appearance of pure colonies on the agar plates and Gram staining reaction. Gram negative, lactose fermenting isolates with colonial appearance resembling $E$. coli that were motile, positive for indole production and negative for oxidase test were subcultured on Sorbitol MacConkey agar and CHROMagarTM MH Orientation. The isolates were further identified using Microbat 12E identification kit.

\subsection{Detection of $E$. coli $0157: \mathrm{H} 7$ serotype}

Twenty-four hour old colonies of isolates confirmed to be $E$. coli were tested with latex dry spot agglutination kit for E. coli O157:H7 (E. coli

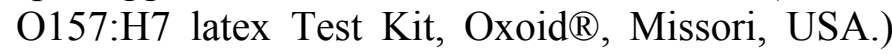
according to the manufacturer' s instruction. Saline $(40 \mu 1)$ was placed on the small rings on both test and control reaction areas of the test card. A portion of the colony was picked with a sterile stick and was carefully emulsified in the saline in the test area and control. The suspension was then spread to cover the reaction area on the card. The $\mathrm{O} 157$ test latex was mixed and 1 drop was added to the emulsified colony and $\mathrm{O} 157$ control latex was mixed and 1 drop was added to the emulsified colony in the control area. The card was rocked for 30 seconds and observed for agglutination. Agglutination indicates the presence of $E$. coli serogroup O157.

The same procedure was repeated to check for H7 antigens. Escherichia coli O157: H7 ATCC 700728 was used as control.

\subsection{DNA extraction from bacterial culture}

Total DNA was extracted from bacteria isolates using commercially available bacteria DNA extraction kit (Jena Bioscience, Germany) according to the manufacturer's instruction as described below.

E. coli were subcultured from Tryptone soy broth containing $25 \%$ glycerol to MacConkey agar plates and incubated for 24 hours at $37^{\circ} \mathrm{C}$. One (1) pure colony was transferred into $1.5 \mathrm{ml}$ microtube and $300 \mu \mathrm{l}$ Cell lysis solution was added into the microtube, $1.5 \mu$ of RNase A solution was added and the solution was mixed by inverting. This was incubated at $37^{\circ} \mathrm{C}$ for 30 minutes and cooled on ice for 1minute. $100 \mu 1$ of Protein precipitation solution was added and vortex vigorously for 30 seconds the solution was centrifuge at $15,000 \mathrm{~g}$ for 5 minute. 
The supernatant was transferred to a clean $1.5 \mathrm{ml}$ microtube containing $300 \mu \mathrm{l}$ isopropanol $>99 \%$. The sample was mixed by inverting gently for 1 minute and centrifuge at $15,000 \mathrm{~g}$ for 1 minute. The supernatant was discarded and the tube was drained briefly on clean absorbent paper, $500 \mu \mathrm{l}$ Washing buffer was added and the tube inverted several times to wash the DNA pellet. The solution was centrifuged at $15,000 \mathrm{~g}$ for 1 minute and the ethanol was discarded carefully. It was then air- dry at room temperature for 15 minutes and $100 \mu \mathrm{l}$ of DNA Hydration Solution was added to the dried DNA pellet. The DNA was hydrated by incubating at $65^{\circ} \mathrm{C}$ for 60 minutes and stored at $4^{\circ} \mathrm{C}$.

\subsection{Multiplex PCR}

Five microliters $(5 \mu \mathrm{l})$ of the prepared cDNA of each sample was used in the multiplex reaction using PCR master mix from Jena Biosciences and primers for $E$. coli $\mathrm{O} 157: \mathrm{H} 7$ to make twenty-five microliters $(25 \mu \mathrm{l})$ reaction mix. The PCR master mix contains a premix of PCR buffer, Magnesium chloride, dNTPs, and Taq Polymerase enzyme in optimized concentrations. Nucleotide sequence of the primers is as shown in Table 1. Primers sequenced published by ${ }^{[8,9]}$ obtained from a commercial company Jena Biosciences, Jena Germany were used for the PCR assay. The primers used were targeted at the conserved region of E. coli O157:H7 nucleoprotein and matrix gene.

Micro amps tubes' containing the PCR reaction mixes were placed in a thermal cycler (Master cycler gradient Eppendorff, Hamburg, Germany) programmed to run as follows:

There was an activation of the Taq polymerase enzyme at $94^{\circ} \mathrm{C}$ for 2 minutes followed by 35 cycles of denaturation of the double stranded DNA at $94^{\circ} \mathrm{C}$ for 20 seconds, primer annealing at $60{ }^{\circ} \mathrm{C}$ for 60 seconds, and an elongation of $60 \mathrm{sec}$ at $72^{\circ} \mathrm{C}$. There was a final extension time $72^{\circ} \mathrm{C}$ for five minutes.

Table 1: Primers and primer sequences used in this study for the identification of E. coli O157: H7

\begin{tabular}{|c|c|c|c|c|}
\hline Primers & Sequences $\left(5^{\prime}-3^{\prime}\right)$ & $\begin{array}{l}\text { Target } \\
\text { gene }\end{array}$ & $\begin{array}{l}\text { Amplicon } \\
\text { size (bp) }\end{array}$ & Reference \\
\hline FLICH7-F & GCGCTGTCGAGTTCTATCGAGC & $\mathrm{fliC}_{\mathrm{h} 7}$ & 625 & {$[8]$} \\
\hline FLICH7-R & CAACGGTGACTTTATCGCCATTCC & & & \\
\hline rfbE-F & CAGGTGAAGGTGGAATGGTTGTC & $\mathrm{rfbE}$ & 296 & [9] \\
\hline rfbE-R & TTAGAATTGAGACCATCCAATAAG & & & \\
\hline AE22 & ATTACCATCCACACAGACGGT & eaeA & 397 & {$[8]$} \\
\hline AE20-2 & ACAGCGTGGTTGGATCAACCT & & & \\
\hline MFS1-F & ACGATGTGGTTTATTCTGGA & hly & 166 & [8] \\
\hline MFS1-R & CTTCACGTCACCATACATAT & & & \\
\hline
\end{tabular}

\subsection{Antimicrobial Susceptibility Testing}

Antimicrobial susceptibility tests were performed by the Kirby-Bauer disc diffusion method using Mueller-Hinton agar (OXOID, UK), according to the Clinical and Laboratory Standards Institute ${ }^{[10]}$. Briefly, biochemically confirmed $E$. coli O157: $\mathrm{H} 7$ isolates were grown in Muller Hinton broth for $6 \mathrm{~h}$ at $37^{\circ} \mathrm{C}$. Turbidity was adjusted to 0.5 McFarland standard and Muller Hinton agar plates were seeded with the cultures. Different antibiotic disks which include Ampicillin, Amoxicillin/Clavulanic acid, Gentamicin,
Pefloxacin, Ciprofloxacin, Cefuroxime, Ceftazidime, and Meropenem (OXOID, UK) were placed on the inoculated medium. Antibiotic sensitivity plates were incubated at $37^{\circ} \mathrm{C}$ for $24 \mathrm{~h}$. E. coli ATCC 25922 was used as quality control strain. The zones of clearing around the disks were measured and compared with Clinical and Laboratory Standards Institute (CLSI) ${ }^{[10]}$, standard and interpreted as sensitive, resistant or intermediate. 


\section{Results}

Out of a total of $78(19.5 \%)$ E. coli isolated from different meat and fish samples in this study, 4 (5.1\%) were identified as E. coli O157:H7 serotype using plate agglutination method and were from meat samples (2), and fish samples (2). The E. coli isolated were further subjected to the multiplex PCR to detect four virulence genes in $E$. coli O157:H7. The multiplex PCR detected more E. coli O157:H7 6 (7.7\%) serotype (Table 1). The E. coli O157:H7 isolates were from beef-1 $(0.8 \%)$, chevon $-1(1.9 \%)$, pork-1 (3.9\%), Sardine fish-2 $(3.0 \%)$ and Titus fish-1 (1.6\%). None was isolated from chicken and turkey.

Out of the six (6) E. coli O157:H7 identified by multiplex PCR assay $3(50 \%)$ carries eaeA, hly,
rfbE and flich7 genes, 3(50\%) harboured flich7, $\mathrm{rfbE}$ and hly gene (Figure 1).

Antibiotic susceptibility profile of the $E$. coli O157:H7 from meat and fish characterized in this study displayed sensitivity to most of the antibiotics used (Figure 2), however, 4 (66.7\%) of the isolates were resistant to one or more antibiotics as shown in Table 3. The resistance rate to Ampicillin and Cefuroxime was the highest $66.7 \%$ each, followed by Gentamicin $50.0 \%$, Amoxicillin/Clavulanic acid, Pefloxacin and Meropenem $16.7 \%$ each. Ciprofloxacin and Ceftazidime had 100\% sensitivity (Figure 3). Multidrug resistance was observed in $3(50.0 \%)$ of the E. coli O157: $\mathrm{H} 7$ isolates (Table 3).

Table 2: Detection of Escherichia coli O157:H7 using plate agglutination method and PCR

\begin{tabular}{|l|l|l|l|}
\hline Sample & No of Samples & \multicolumn{2}{|l|}{ Presence of E. coli O157: H7 } \\
Cultural & \multicolumn{1}{|c|}{ PCR } \\
\hline $\begin{array}{l}\text { Meat } \\
\text { Samples }\end{array}$ & 280 & 3 & 3 \\
\hline $\begin{array}{l}\text { Fish } \\
\text { Samples }\end{array}$ & 120 & 1 & 3 \\
\hline Total & 400 & 4 & 6 \\
\hline
\end{tabular}

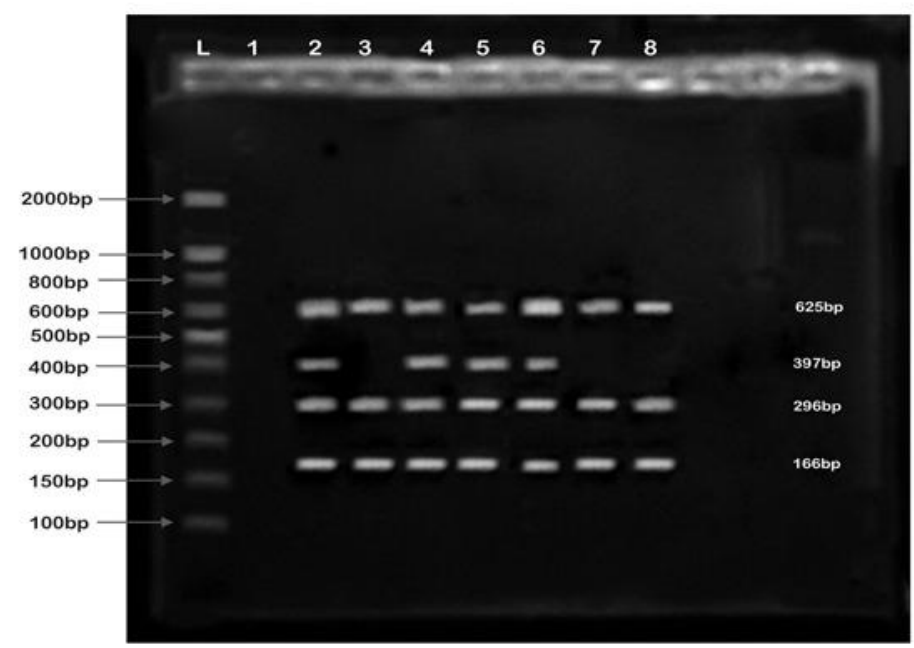

Figure 1: Gel electrophoresis of amplicons showing multiplex PCR to detect flic, eae. Hly and $r f b E$ genes of $E$. coli O157:H7 in E. coli isolates. Lane L: DNA ladder (100 bp), lane 1: negative control, lane 2: positive control and lanes 3-8: amplicons from the isolates 


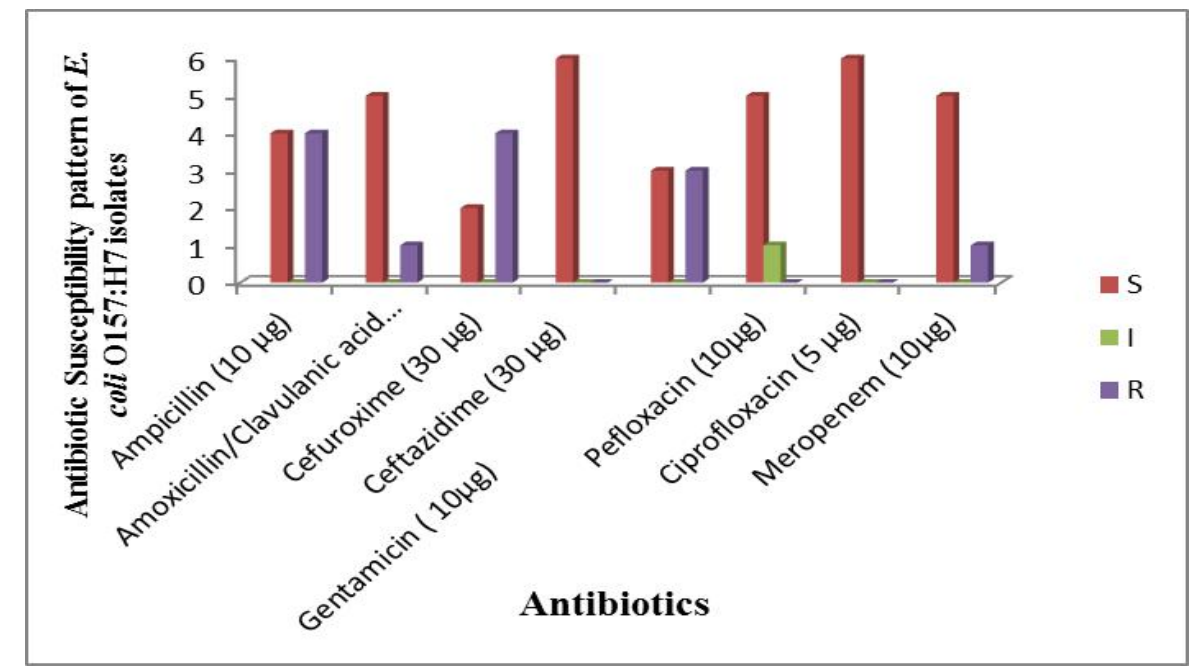

Figure 2: Antibiotic susceptibility pattern of $E$. coli $0157:$ H7 isolates Antibiotics tested ( $\mu \mathrm{g} / \mathrm{ml})$ E. coli O157: $H 7$ isolates $(n=6) S$, sensitive; $R$, resistant; $I$, intermediate

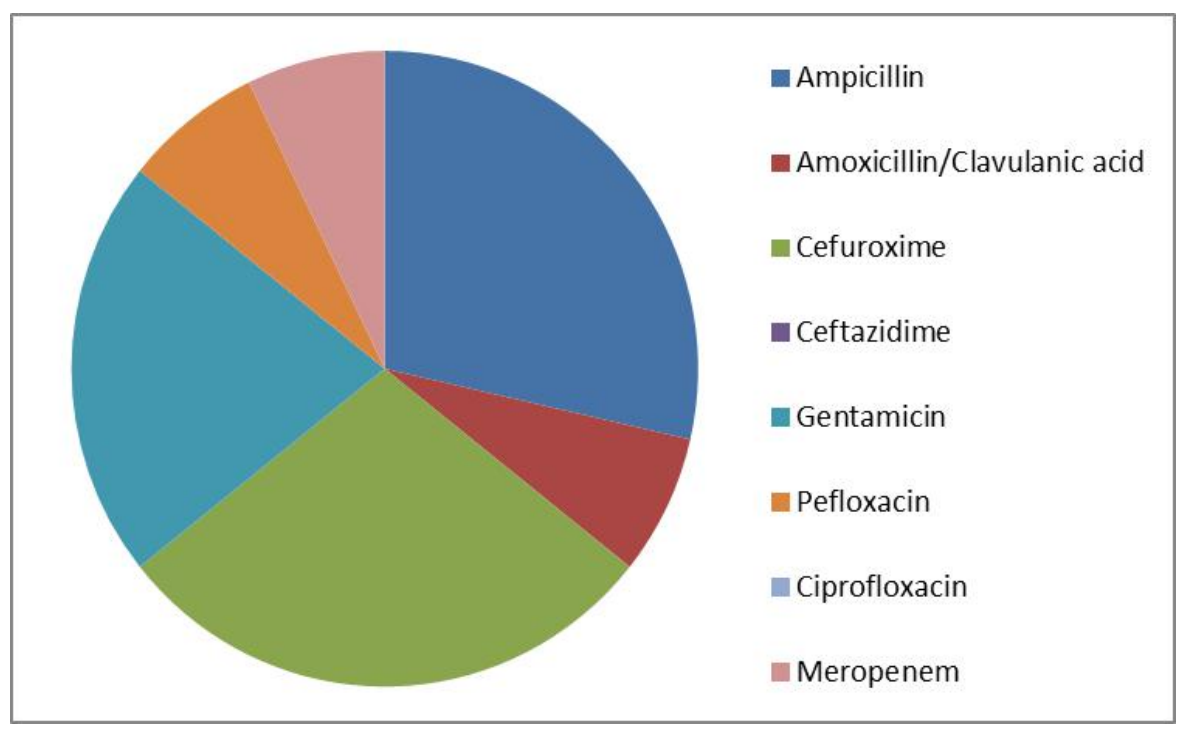

Figure 3: Resistance profile of $E$. coli $0157: \mathrm{H7}$ isolates

Table3: Resistance pattern of $E$. coli O157: H7 showing the resistant phenotype

\begin{tabular}{|l|l|l|} 
S/N & \multicolumn{1}{c|}{ No. of Resistant Isolates } & Resistant Phenotype \\
\hline 1 & 1 & AMP, CXM \\
\hline 2 & 1 & AMP, CXM, GEN \\
\hline 3 & 1 & AMP, CXM, GEN, PEF \\
\hline 4 & 1 & \\
\hline
\end{tabular}

Note: AMP - Ampicillin, AMC - Amoxicillin/Clavulanic acid, CXM - Cefuroxime, GEN - Gentamicin, PEF Pefloxacin, MEM-Meropenem 


\section{Discussion}

This study isolated $78(19.5 \%) E$. coli isolates from different meat and fish samples. Plate agglutination method identified only 4 (5.1\%) isolates as E. coli $\mathrm{O} 157: \mathrm{H} 7$ serotype while the multiplex PCR detected $6(7.7 \%)$ E. coli $\mathrm{O} 157: \mathrm{H} 7$ serotype. In Nigeria, some studies have reported various prevalence of $E$. coli $\mathrm{O} 157: \mathrm{H} 7$ [11, 12, 13, 14]. Also E. coli $\mathrm{O} 157: \mathrm{H} 7$ have been isolated from the intestines of healthy cattle, deer, goats, and sheep [15].

Olatoye, Amosun and Ogundipe ${ }^{[16]}$ reported a higher prevalence of E. coli O157: $\mathrm{H} 7$ in beef and in chicken from Ibadan. Enabulele, and Uraih, [17] isolated E. coli $\mathrm{O} 157: \mathrm{H} 7$ from meat sold at abattoirs and ready-to-eat grilled "Suya" meat sold in Benin City. Different authors reported higher prevalence $E$. coli $\mathrm{O} 157: \mathrm{H7}$ in different meat and fish from various parts of Nigeria compared with that obtained in this study $[18,19,20,21,22,23]$.

Half $(50 \%)$ of the E. coli $\mathrm{O} 157: \mathrm{H} 7$ isolates identified by multiplex PCR assay carries eaeA, hly, $\mathrm{rfbE}$ and flich7 genes, and the remaining, 3(50\%) harboured flich7, rfbE and hly genes. Hessain, et al. [24] reported that $3(27.27 \%)$ out of 11 E. coli O157:H7 isolated from raw beef, chicken and mutton carried eae. Oloyede, Afolabi, and Olalowo [23], did not detect any eaeA and hlyA virulence genes in E. coli $\mathrm{O} 157: \mathrm{H} 7$ isolated.

E. coli $\mathrm{O} 157: \mathrm{H} 7$ isolated in this study had a high resistance rate to Ampicillin, Cefuroxime, $66.7 \%$ each and Gentamicin 50.0\%. Ciprofloxacin and Ceftazidime had $100 \%$ sensitivity. $3(50.0 \%)$ of the E. coli O157: $\mathrm{H} 7$ isolates were resistance to three or more antibiotics. Previous studies such as Aibinu, et al. ${ }^{[18]}$ recorded $100 \%$ sensitivity to Meropenem. Reuben, Owuna, (2013) reported that $15(78.9 \%)$ and $17(89.5 \%)$ of their isolates were sensitive to Ciprofloxacin and Gentamicin. Goncuoglu, et al. ${ }^{[26]}$ had $100 \%$ sensitivity to Gentamicin and Ciprofloxacin for E. coli O157:H7 from cattle and sheep. Opere, et al. ${ }^{[27]}$ also recorded $100 \%$ and $58.33 \%$ sensitivity to Gentamicin and Augmentin respectively. The studies of Abuelhassan, Fatima and Igwe, [28, 28, 22] reported $100 \%$ sensitivity of E. coli O157: H7 to Gentamicin, $20 \%$ resistant to Ciprofloxacin.
Limitations of the study: Often times, it was difficult obtaining samples from the retailers because their unhygienic attitude could be reported and poor method of sample preservation limit the number of samples to be collected.

\section{Conclusion}

E. coli $\mathrm{O} 157: \mathrm{H} 7$ is emerging foodborne pathogens whose outbreak can lead to death if not properly monitored. Isolation of E. coli $\mathrm{O} 157: \mathrm{H} 7$ in this study indicates the possible risk of food poisoning by $E$. coli $\mathrm{O} 157: \mathrm{H} 7$ among individuals in Ibadan.

\section{References}

1 Robinson AL, McKillip $\mathbf{J}$. Biology of Escherichia coli O157:H7 in human health and food safety with emphasis on sublethal injury and detection. In Mendez - Vilas (ed), Current research, technology and education topics in applied microbiology and microbial biotechnology, Formatex, Badajoz, Spain, 2010; pp.1096-1105.

2 Mainil JG, Daube G. Verotoxigenic Escherichia coli from animals, humans and foods: who's who? J Appl Microbiol 2005; 98(6): 1332-1344 DOI:10.1111/j.13652672.2005.02653.x

3 Yoon JW, Hovde CJ. All blood, no stool: enterohemorrhagic Escherichia coli $\mathrm{O} 157: \mathrm{H} 7$ infection. J Vet Sci 2008; 9(3): 219-231 DOI: 10.4142/jvs.2008.9.3.219

4 Welinder-Olsson C, Kaijser B. Enterohemorrhagic Escherichia coli (EHEC). Scand J Infect Dis 2005; 37(6-7): 405-416 DOI: $\underline{10.1080 / 00365540510038523}$

5 Robins-Browne RM. The relentless evolution of pathogenic Escherichia coli. Clin Infect Dis 2005; 41(6): 793-794 DOI: 10.1086/432725

6 Spickler, AR. Enterohemorrhagic Escherichia coli Infections. 2016, Pp.1-16 Retrieved from http://www.cfsph.iastate.edu/DiseaseInfo/facts heets.php

7 Chapman PA, Cerdan Malo AT, Ellin M, Ashton R, Harkin. Escherichia coli $\mathrm{O} 157$ in cattle and sheep at slaughter, on beef and lamb carcasses and in raw beef and lamb products in 
South Yorkshire, UK. Int J Food Microbiol 2001; 64(1-2): 139-150 DOI: 10.1016/s01681605(00)00453-0

8 Sarimehmetoglu B, Aksoy MH,Ayaz ND,Ayaz Y, Kuplulu O, Kaplan YZ. Detection of Escherichia coli $\mathrm{O} 157: \mathrm{H} 7$ in ground beef using immunomagnetic separation and multiplex PCR. Food Cont 2009; 20: 357-361.

9 Jeshveen SS, Chai LC, Pui CF, Son R. Optimization of multiplex PCR conditions for rapid detection of Escherichia coli $\mathrm{O} 157: \mathrm{H} 7$ virulence genes. Int Food Res J 2012; 19(2): 461-466.

10 CLSI. Clinical and Laboratory Standards Institute. Performance Standards for Antimicrobial Susceptibility Testing, 23rd Informational Supplement. CLSI Document M100-S23, Clinical and Laboratory Standards Institute, Wayne 2013, 33 (1)

11 Ogunsanya TL, Rotimi VO, Adenuga A. A study of the etiological agents of childhood diarrhea in Lagos, Nigeria. J Med Microbiol 1994; 40: 10-14.

12 Okeke IN, Lamikanra A, Steinruck H, Kaper JB. Characterization of Escherichia coli strains from cases of childhood diarrhea in provincial southwestern Nigeria. J Clin Microbiol 2000; 38(1): 7-12

13 Olorunshola ID, Smith SI, Coker AO. Prevalence of EHEC O157:H7 in patients with diarrhoea in Lagos, Nigeria. APMIS 2000; 108(11): 761-763 DOI: $10.1034 / \mathrm{j} .1600-$ 0463.2000.d01-26.x

14 Isibor JO, Esumeh FI, Egbagbe IDS. Screening for Escherichia coli 157:H7 in diarrheic patients in Benin City, Nigeria. Microbiol Biotech. Res 2011; 1(4): 1-4.

15 Tizeta, B.A. Prevalence and Antibiotic Susceptibility Pattern of Escherichia coli O157:H7 in raw beef, mutton and chevon at Addis Ababa abattoir enterprise and selected retail shops, Addis Ababa, Ethiopia. Unpublished MSc. thesis, School of Graduate Studies of Addis Ababa University, DebreZeit, Ethiopia

16 Olatoye IO ,Amosun EA,Ogundipe GA. Multidrug Resistant Escherichia coli O157 Contamination of Beef and Chicken in Municipal Abattoirs of Southwest Nigeria. Nat Sci 2012; 10(8): 125-132.

17 Enabulele SA,Uraih N. Enterohemorrhagic Escherichia coli O157:H7: Prevalence in meat and vegetables sold in Benin City Nigeria. Afri J Microbiol Res 2009; 3(5): 276-279.

18 Aibinu I.E, Peters RF, Amisu KO, Adesida SA, Ojo MO, Odugbemi T. Multidrug resistance in E. coli $\mathrm{O} 157$ strains and public health implication. J Am Sci 2007; 3(3): 22-33.

19 Dahiru M,Uraih N,Enabulele SA,SHamsudden U. Prevalence of Escherichia coli O157:H7 in fresh and roasted beef in Kano city, Nigeria. BAJOPAS 2008; 1 (1): 39-42 DOI: 10.4314/bajopas.v1i1.57513

20 Salome YT, Jacob KPK,Mohammed B, Junaidu K, Veronica JU, Sabo EY, Andrew JN. Occurrence of Escherichia coli $\mathrm{O} 157$ in Retailed-Beef and Related Meat Products in Zaria, Nigeria. Food Nut Sci 2014; 5: 481-487 DOI: $10.4236 /$ fns.2014.56057

21 Olatoye IO. The incidence and antibiotics susceptibility of Escherichia coli $0157: \mathrm{H} 7$ from beef in Ibadan Municipal, Nigeria. $\boldsymbol{A} \boldsymbol{f} \boldsymbol{r} \boldsymbol{J}$ Biotech 2010; 9(8): 1196 -1199.

22 Igwe JC, Onaolapo JA, Ehimidu JO, Bolaji RO, Tytler AB, Ojiego BO, Kachallah M, Okafo NC, Musa A, Sidi MT, Salihu MS. Antibiotic Susceptibility Profile of E. coli Serotype 0157:H7 in ABUTH, Zaria, Nigeria. IJTDH 2016; $11(1): \quad 1-8 \quad$ DOI: 10.9734/IJTDH/2016/13112

23 Oloyede AR, Afolabi OR, Olalowo OS. Molecular detection of virulence genes and antibiotic resistance patterns of Escherichia coli $\mathrm{O} 157: \mathrm{H} 7$ isolated from raw beef sold in Abeokuta, South-West Nigeria. Nig J Biotech 2016; 31: 15-21 DOI: 10.4314/njb.v31i1.3

24 Hessain AM, Al-Arfaj AA, Zakri AM, ElJakee JK, Al-Zogibi OG, Hemeg HA, Ibrahim IM. Molecular characterization of Escherichia coli $\mathrm{O} 157: \mathrm{H} 7$ recovered from meat and meat products relevant to human health in Riyadh, Saudi Arabia. Saudi J Biol Sci 2015; 22(6): 725-729 DOI: 10.1016/j.sjbs.2015.06.009

25 Reuben RC,Owuna G. Antimicrobial resistance patterns of Escherichia coli O157:H7 from Nigerian fermented milk samples in Nasarawa 
State, Nigeria. Int J Pharm Sci 2013; 2 (3): 38-44.

26 Goncuoglu M, Ormanci FSB, Ayaz ND, Erol I. Antibiotic resistance of Escherichia coli O157:H7 isolated from cattle and sheep. Ann Microbiol 2010; 60: 489-494.

27 Opere BO,Omonigbehin EA,Ezeh AR, Mbacha MI, Fowora MA, Smith SI, Anwoju FO. Antimicrobial Susceptibility Testing of Enterohaemorharrgic Escherichia coli Isolated from Rectal Swab of Cattle in Oko Oba Abattoir, Agege, Lagos. Int J App. Sci and Tech 2013; 3(3): 85-90.
28 Abuelhassan NN, Mutalib SA, Muin NM Doni EMF, Yusoff WNW. Antibiotic resistance pattern among Escherichia coli O157:H7 isolated from retail imported frozen meat, Asian Jr of Microbiol Biotech Env Sc 2014; 16 (3): 739-744

29 Fatima M, Gambo L, Mukhtar GL, Inabo HI, Jatau ED, Shitu AM. Antibacterial susceptibility profile of Escherichia coli O157:H7 from shallow wells in parts of Katsina State, Nigeria. Biosciences Research in Today's World. 2016; 2: 1-7 DOI: $\underline{10.5281 / \text { zenodo. } 216890}$ 